\title{
PEMAHAMAN MASYARAKAT TERHADAP PEMBATASAN USIA MINIMAL UNTUK MELANGSUNGKAN PERKAWINAN
}

Oleh :

\author{
Supianto \\ Email:supianto@uij.ac.id \\ Universitas Islam Jember \\ Nanang Tri Budiman \\ Email : ntbudiman@gmail.com \\ Universitas Islam Jember \\ Dwi Fefri Kurniasari \\ Email : $\underline{\text { dwi.fefri72@gmail.com }}$ \\ Universitas Islam Jember
}

\begin{abstract}
Abstrak
Ketentuantentang batasan usia minimal dalam Undang-Undang Perkawinantelahdiubah dengan lahirnya Perubahan Undang-Undang Perkawinan Nomor 16 Tahun 2019. Dalam undang-undang ini batas minimal umur perkawinan bagi wanita dipersamakan dengan batas minimal umur perkawinan bagi pria, yaitu 19 (Sembilan belas) tahun. Batas usia dimaksud dinilai telah matang jiwa raganya untuk dapat melangsungkan perkawinan agar dapat mewujudkan tujuan perkawinan secara baik tanpa berakhir pada perceraian dan mendapat keturunan yang sehat dan berkualitas. Dari hasil penelitian ditemukan bahwa masyarakat Desa Pontang Ambulu tidak mengetahui tentang adanya perubahan batasan minimal untuk melangsungkan perkawinan juga tidak mengetahui tentang adanya peraturan Undang- Undang No.16 Tahun 2019 yang menyebutkan perubahan batasan usia minimal perkawinan.
\end{abstract}

Kata kunci : perubahan, batas usia minimal, perkawinan

\begin{abstract}
Provisions regarding the minimum age limit in the Marriage Law have been amended with the birth of Amendment to the Marriage Law Number 16 Year 2019. In this law the minimum age of marriage for women is equal to the minimum age of marriage for men, which is 19 (Nineteen) year. The age limit is considered to have matured body and soul to be able to carry out marriage in order to realize the purpose of marriage properly without ending in divorce and get healthy and quality offspring. From the results of the study it was found that the people of the Village of Pontang Ambulu did not know about the change in the minimum limits to carry out the marriage nor did they know about the existence of the Law No. 16 of 2019 which mentions changes in the minimum age limit for marriage.
\end{abstract}

Keywords: change, minimum age limit, marriage 


\section{PENDAHULUAN}

\subsection{Latar Belakang}

Perkawinan merupakan peristiwa yang sangat penting bagi perjalanan hidup manusia. Disamping membawa kedua mempelai kehidupan baru yang berbeda, perkawinan juga secara otomatis akan mengubah status keduanya. Setelah perkawinan, kedua belah pihak akan menerima beban yang berat dan tanggung jawab sesuai kodrat masing-masing. Tanggung jawab dan beban itu bukanlah sesuatu yang mudah dilaksanakan, sehingga mereka harus memikul tanggung jawab tersebut dan melaksanakannya.

Rumah tangga atau keluarga adalah unit terkecil dalam masyarakat sebagai wadah dan proses pergaulan hidup. ${ }^{1}$ Rumah tangga yang harmonis bias terjadi karena beberapa faktor diantaranya kenyamanan, kecocokan, adanya tujuan dan kepercayaan. Sebaliknya, rumahtangga yang tidak harmonis terjadi karena beberapa faktor diantaranya tidak adanya kecocokan dan sering terjadi konflik. Konflik dalam kehidupan berumah tangga memang tidak biasa untuk dipung kiri. Ada pasangan yang mampu menyelesaikan konflik itu dengan baik, namun konflik yang tidak tertangani dengan baik akan berakhir dengan tidak baik akan berujung dengan tindak kekerasan.

Dari segipsikis (mental), baik lakilaki maupun perempuan, kesiapan mental tak kalah pentingnya ketimbang kesiapan fisik. Mengingat kehidupan ini tidak selalu ramah bahkan kadang kala kejam, sangat mutlak diperlukan kesiapan mental, kesabaran, dan keuletan. Prinsip kematangan calon mempelai juga dimaksudkan karena perkawinan itu mengandung tujuan luhur. ${ }^{2}$

Untuk dapat mewujudkan tujuan perkawinan, salah satu syaratnya adalah bahwa para pihak yang akan melakukan perkawinan harus telah masak jiwa raganya. Olehkarenaitu, di dalamUndang-Undang No. 1 Tahun 1974 ditentukan batas umur minimal untuk melangsungkan perkawinan. Ketentuan mengenai batas umur minimal tersebut terdapat di dalamPasal 7 Ayat 1 Undang-Undang No. 1 Tahun 1974 yang mengatakan bahwa "Perkawinan hanya diizinkan jika pihak pria sudah mencapai usia 19 tahun dan pihak wanita sudah mencapai usia 16 tahun". 3

Ketentuan dalam Pasal 7 Ayat 1 Undang-Undang No. 1 Tahun 1974 tersebut telah diubah dengan lahirnya UndangUndang Republik Indonesia Nomor 16 Tahun 2019 tentang Perubahan Atas Undang-Undang Nomor 1 Tahun 1974 
${ }^{1}$ Soerjono Soekanto, Sosiologi Keluarga Tentang Ikhwal Keluarga, Remaja dan Anak, (Jakarta: Rineka Cipta, 2009), hlm. 1
${ }^{2}$ Rahmat Hakim, Hukum Perkawinan Islam, (Bandung: CV Pustaka Setia, 2000), hal. 139-141 ${ }^{3}$ Ibid., hal. 5 
tentang Perkawinan disahkan Presiden RI pada tanggal 14 Oktober 2019 di Jakarta. Undang-Undang Nomor 16 Tahun 2019 tentang Perubahan Atas Undang-Undang Nomor 1 Tahun 1974 tentang Perkawinan mulai berlaku setelah diundangkan pada tanggal 15 Oktober 2019.

Ketentuan Pasal 7 ayat (1) UndangUndang Nomor 1 Tahun 1974 menyatakan bahwa perkawinan hanya diizinkan apabila pihak pria mencapai umur 19 (Sembilan belas) tahun dan pihak wanita sudah mencapai usia 16 (enam belas) tahun, ketentuan tersebut memungkinkan terjadinya perkawinan dalam usia anak pada anak wanita karena dalam Pasal 1 angka

1 Undang-Undang Nomor 1 Tahun 1974 tentang Perkawinan diartikan bahwa anak adalah seseorang yang belum berusia 18 (delapa nbelas) tahun, termasuk anak yang masih dalam kandungan.

Menurut penjelasan umum UndangUndang Nomor 16 Tahun 2019 tentang Perubahan Atas Undang-Undang Nomor 1 Tahun 1974 tentang Perkawinan Perubahan, norma dalam Undang-Undang Nomor 1 Tahun 1974 tentang Perkawinan ini menjangkau batas usia untuk melakukan perkawinan, perbaikan norma menjangkau dengan menaikkan batas minimal umur perkawinan bagi wanita. Dalam hal ini batas minimal umur perkawinan bagi wanita dipersamakan dengan batas minimal umur perkawinan bagi pria, yaitu 19 
(Sembilan belas) tahun. Batas usia dimaksud dinilai telah matang jiwa raganya untuk dapat melangsungkan perkawinan agar dapat mewujudkan tujuan perkawinan secara baik tanpa berakhir pada perceraian dan mendapat keturunan yang sehat dan berkualitas.

Desa Pontang merupakan salah satu desa di Kecamatan Ambulu Kabupaten Jember. Letak desa Pontang berada disisi sebelah timur wilayah administratif $\mathrm{Ke}$ camatan Ambulu, yang berbatasan dengan dengan Kecamatan Jenggawah dan Kecamatan Tempurejo. Luas wilayah Desa Pontang adalah 919,76 ha, yang terdiri dari wilayah pemukiman seluas 288,303 ha dan wilayah pertanian berupa persawahan seluas 464,104 ha serta lahan pekarangan seluas 64,130 ha.

Jumlah penduduk Desa Pontang Tahun 2019 adalah 11.473 jiwa yang terdiri dari 3.749 kepala keluarga (KK). Sebagian besar warga desa Pontang memiliki mata pencaharian sebagai petani. Selain petani Mata pencaharian warga desa Pontang adalah buruh tani dan buruh migran. Keadaan masyarakat dengan mata pencaharian buruh tani dan buruh migran ini berdampak pada relatif rendahnya tingkat pendidikan warga desa Pontang. Begitu pula bila dikaitkan dengan pengetahuan terhadap peraturan perundang-undangan, seperti peraturan tentang batasan usia minimal untuk melakukan perkawinan. 


\subsection{Rumusan Masalah}

Berdasarkan uraian dalam latar belakang diatas, maka didapatkan rumusan masalah yang akan penulis ajukan dalam penelitian ini sebagai berikut:

1. Bagaimana pemahaman masyarakat terhadap Pembatasan Usia Minimum Untuk Melangsungkan Perkawinan Berdasarkan UU No. 16 Tahun 2019 Tentang Perubahan Atas UU 1 Tahun 1974 Tentang Perkawinan Di Desa Pontang Kecamatan Ambulu, Kabupaten Jember?

2. Bagaimana dampak dari pemahaman masyarakat tentang Pembatasan Usia Minimum Untuk Melangsungkan Perkawinan Berdasarkan UU No. 16 Tahun 2019 Tentang Perubahan Atas UU 1 Tahun 1974 Tentang Perkawinan terhadap perkawinan dibawah umur Di Desa Pontang Kecamatan Ambulu, Kabupaten Jember?

\section{PEMBAHASAN}

Perkawinan merupakan suatu peristiwa yang sangat penting dalam penghidupan masyarakat kita, sebab perkawinan itu tidak hanya menyangkut wanita dan pria bakal mempelai saja, tetapi juga orang tua kedua belah pihak, saudara-saudaranya, bahkan keluarga-keluarga mereka masing- masing. Menurut hukum adat (Jawa) pada umumnya di Indonesia perkawinan itu 
bukan saja berarti sebagai "Perikatan perdata", tetapi juga merupakan "Perikatan adat" dan sekaligus merupakan perikatan kekerabatan dan ketetanggaan.

Terjadinya suatu ikatan perkawinan bukan semata mata membawa akibat terhadap hubungan-hubungan keperdataan, seperti hak dan kewajiban orang tua, tetapi juga menyangkut hubungan-hubungan adat istiadat kearisan, kekeluargaan, kekerabatan dan ketetanggaan serta menyangkut upacara-upacara adat dan keagamaan. Begitu juga menyangkut kewajiban mentaati perintah dan larangan keagamaan, baik dalam hubungan manusia dengan Tuhannya (ibadah) maupun hubungan manusia se- sama manusia (mu'amalah) dalam pergau- lan hidup agar selamat di dunia dan selamat di akhirat. ${ }^{4}$

Dalamhukum adat perkawinan bukan hanya merupakan peristiwa penting bagi mereka yang masih hidup saja, tetapi perkawinan juga merupakan peristiwa yang sangat berarti serta yang sepenuhnya mendapat perhatian dan diikuti oleh arwaharwah para leluhur dari kedua belah pihak. Dan dari arwah-arwah inilah kedua belah pihak beserta seluruh keluarganya mengharapkan restu bagi kedua mempelai, hingga mereka ini setelah nikah selanjutnya dapat hidup rukun bahagia sebagai suami-

${ }^{4}$ Hilman Hadikusuma, Hukum Perkawinan Indonesia Menurut Perundangan, Hukum Adat, Hukum Agama, (Bandung: Mandar Maju, 1990), hal. 8 
istri sampai "kaken-kaken ninen-ninen", yang merupakanistilah Jawa yang artinya sampai kaki-kaki dan nini-nini. ${ }^{5}$

Menurut Pasal 1 Undang-Undang Nomor 1 Tahun 1974 Tentang Perkawinan, Perkawinan adalah: "Ikatan lahir bathin antara seorang pria dengan seorang wanita sebagai suami isteri dengan tujuan membentuk keluarga (rumah tangga) yang bahagia dan kekal berdasarkan Ketuhanan Yang Maha Esa". Undang-Undang Nomor 1 Tahun 1974 Pasal 1 merumuskan bahwa ikatan suami isteri berdasarkan Ketuhanan Yang Maha Esa, perkawinan merupakan perikatan yang suci. Perikatan tidak dapat melepaskan dari agama yang dianut suami isteri. Hidup bersama suami isteri dalam perkawinan tidak semata-mata untuk tertibnya hubungan seksual tetap pada pasangan suami isteri, tetapi dapat membentuk rumah tangga yang bahagia, rumah tangga yang rukun, aman dan harmonis antara suami isteri. Perkawinan salah satu perjanjian suci antara seorang laki-laki dengan seorang perempuan untuk membentuk keluarga bahagia. $^{6}$

Ikatan lahir adalah hubungan formal yang dapat dilihat karena dibentuk menurut Undang-Undang, hubungan mana mengikat kedua pihak dan pihak lain dalam masya-

\footnotetext{
${ }^{5}$ Soerojo Wignjodioera, Pengantar dan Asas-asas Hukum Adat, (Jakarta: Gunung Agung, 1995), hal. 122
}

rakat. Ikatan batin adalah hubungan tidak formal yang dibentuk dengan ke-mauan bersama yang sungguh-sungguh, yang mengikat kedua pihak saja. Ikatan lahir batin itu dimaksudkan bahwa hubu-ngan suami istri tidak boleh semata-mata hanya berupa ikatan lahiriah saja dalam makna seorang pria dan wanita hidup bersama sebagai suami istri dalam ikatan formal, tetapi juga kedua-duanya harus membina ikatan batin. Tanpa ikatan batin, ikatan lahir mudah sekali terlepas. Jalinan ikatan lahir dan ikatan batin itulah yang menjadi pondasi yang kokoh dalam mem-bangun dan membina keluarga yang bahagia dan kekal. $^{7}$

Antara seorang pria dan seorang wanita, artinya dalam satu masa ikatan lahir batin itu hanya terjadi antara seorang pria dan seorang wanita saja. Seorang pria artinya seorang yang berjenis kelamin pria, sedangkan seorang wanita artinya seseorang yang berjenis kelamin wanita. Jenis ke- lamin ini kodrat (karunia Tuhan), bukan bentukan manusia. Suami istri adalah fungsi masing-masing pihak sebagai akibat dari adanya ikatan lahir batin. Tidak ada ikatan lahir batin berarti tidak pula ada fungsi sebagai suami istri. ${ }^{8}$

\footnotetext{
${ }^{6}$ UU No. 1 tahun 1974 Tentang Perkawinan Dan Kompilasi Hukum Islam, (Bandung: Citra Umbara, 2007), hal. 138
} 
${ }^{7}$ Mohammad Daud Ali, Hukum Islam dan Peradilan Agama (Kumpulan Tulisan), (Jakarta: Raja Grafindo Persada, 1997), hal. 27

${ }^{8}$ Abdul Kadir Muhammad, Hukum Perdata Indonesia, (Bandung: Citra Aditya Bakti, 2001), hal. 74 
Menurut ketentuan Pasal 1 Undangundang Nomor 1 Tahun 1974 tentang Perkawinan, tujuan dari perkawinan ialah membentuk keluarga / rumah tangga yang bahagia dan kekal berdasarkan Ketuhanan Yang Maha Esa. Membentuk keluarga artinya membentuk kesatuan masyarakat terkecil yang terdiri dari suami, istri, dan anak-anak. Membentuk rumah tangga artinya membentuk kesatuan hubungan suami istri dalam satu wadah yang disebut rumah kediaman bersama. Bahagia artinya ada kerukunan dalam hubungan antara suami dan istri, atau antara suami, istri, dan anakanak dalam rumah tangga. Kekal artinya berlangsung terus menerus seumur hidup dan tidak boleh diputuskan begitu saja atau dibubarkan menurut kehendak pihakpihak. $^{9}$

Hukum Adat tidak mengenal batasan umur dewasa ataupun belum dewasa.

Dalam Hukum Adat tidak dikenal fiksi seperti dalam Hukum Perdata. Hukum Adat hanya mengenal secara insidental saja apakah seseorang itu, berhubungan dengan umur dan perkembangan jiwanya patut dianggap cakap atau tidak, mampu atau tidak mampu melakukan perbuatan hukum tertentu dalam hubungan hukum tertentu pula.

Ukuran mengenai kedewasaan menurut Hukum Adat lebih condong pada sisi

${ }^{9}$ Abdul Kadir Muhammad, Hukum Perdata kepribadian seseorang seperti sudah baligh, mampu mencari nafkah, bertanggung jawab untuk diri sendiri dan mampu berkeluarga dan mendapatkan keturunan.Pengaturan mengenai perkawinan dibawah umur dalam Hukum Adat memang tidak ada. Sebab dalam prakteknya terdapat kasus-kasus yang menunjukkan adanya perkawinan gantung. Perkawinan gantung dilakukan dimasa kanak-kanak namun, mereka belum dapat bercampur satu sama lainnya.

Kompilasi Hukum Islam memuat aturan yang kurang lebih sama dengan aturan yang dimuat oleh Undang-Undang Perkawinan. Batas usia kawin dalam pasal 15 KHI sama dengan pasal 7 UndangUndang Perkawinan. Demikian halnya dengan dispensasi kawin. Bedanya, dalam KHI disebutkan alasan mengapa dispensasi kawin itu diberikan, yaitu untuk kemaslahatan keluarga dan rumah tangga. ${ }^{10}$

Kenyataan dilapangan menunjuk-kan bukannya melahirkan kemaslahatan keluarga dan rumah tangga, perkawinan dibawah umur justru banyak berujung pada perceraian. Dampak lain yang lebih luas seperti meningkatnya angka kematian ibu saat hamil atau melahirkan lantaran usia yang masih belia.

Berdasarkan Undang-Undang Republik Indonesia yang berlaku hingga sekarang sekarang, pengertian dewasa dan belum 
Indonesia, (Bandung: Citra Aditya Bakti, 2001), hal. 74
${ }^{10}$ Kompilasi Hukum Islam, Fokus Media, 2005 
dewasa belum ada pengertiannya. UndangUndang Nomor 1 Tahun 1974 tentang Perkawinan, hanya mengatur tentang, Izin orang tua bagi orang yang akan melangsungkan perkawinan apabila belum mencapai umur 21 tahun (Pasal 6 ayat 2) artinya pria maupun wanita yang ingin menikah harus mendapat izin orang tua apabila belum genap 21 tahun, umur minimal untuk diizinkan melangsungkan perkawinan, yaitu pria 19 tahun dan wanita 16 tahun( Pasal 7 ayat 2), anak yang belum mencapai umur 18 tahun atau belum pernah kawin, berada dalam kekuasaan orang tua (Pasal 47 ayat 2), anak yang belum mencapai umur 18 tahun atau belum pernah kawin, berada di bawah kekeuasaan orang tuanya, berada di bawah kekuasaan wali (Pasal 50 ayat 1).

Ketentuandalam Pasal 7 Ayat 1 Undang-Undang No. 1 Tahun 1974 tersebut telah diubah oleh Undang-Undang Republik Indonesia Nomor 16 Tahun 2019 tentang Perubahan Atas Undang-Undang Nomor 1 Tahun 1974 tentang Perkawinan disahkan pada tanggal 14 Oktober 2019. Pasal 7 ayat (1) Undang-Undang Nomor 1 Tahun 1974 menyatakan bahwa perkawinan hanya diizinkan apabila pihak pria mencapai umur 19 (sembilan belas) tahun dan pihak wanita sudah mencapai usia 16 (enam belas) tahun, ketentuan tersebut memungkinkan terjadinya perkawinan dalam usia anak pada anak wanita karena dalam Pasal 
Perubahan Atas Undang-Undang Nomor 23

Tahun 2002 tentang Pelindungan Anak didefinisikan bahwa anak adalah seseorang yang belum berusia 18 (delapan belas) tahun, termasuk anak yang masih dalam kandungan.

Menurut penjelasan umum UndangUndang Republik Indonesia Nomor 16 Tahun 2019 tentang Perubahan Atas Undang-Undang Nomor 1 Tahun 1974 tentang Perkawinan Perubahan norma dalam Undang-Undang Nomor 1 Tahun 1974 tentang Perkawinan ini menjangkau batas usia untuk melakukan perkawinan, perbaikan norma menjangkau dengan menaikkan batas minimal umur perkawinan bagi wanita. Dalam hal ini batas minimal umur perkawinan bagi wanita dipersamakan dengan batas minimal umur perkawinan bagi pria, yaitu 19 (sembilan belas) tahun.

Batas usia dimaksud dinilai telah matang jiwa raganya untuk dapat melangsungkan perkawinan agar dapat mewujudkan tujuan perkawinan secara baik tanpa berakhir pada perceraian dan mendapat keturunan yang sehat dan berkualitas. Diharapkan juga kenaikan batas umur yang lebih tinggi dari 16 (enam belas) tahun bagi wanita untuk kawin akan mengakibatkan laju kelahiran yang lebih rendah dan menurunkan resiko kematian ibu dan anak. Selain itu juga dapat terpenuhinya hak-hak anak sehingga mengoptimalkan tumbuh kembang anak termasuk pendampingan 
orang tua serta memberikan akses anak terhadap pendidikan setinggi mungkin.

Tidak ada ketentuan yang mengatur tentang "yang belum dewasa dan dewasa" dalam Undang-Undang Nomor 1 tahun 1974 tentang Perkawinan Undang-Undang Nomor 16 Tahun 2019 tentang Perubahan Atas Undang-Undang Nomor 1 Tahun 1974 tentang Perkawinan ini dan tidak ada larangan menikah di bawah umur secara eksplisit. Dalam pasal 7 Undang-Undang Nomor 16 Tahun 2019 tentang Perubahan Atas Undang-Undang Nomor 1 Tahun 1974 tentang Perkawinan disebutkan, untuk dapat menikah, pria dan wanita harus sudah mencapai umur 19 tahun. Meski demikian, penyimpangan terhadap batas usia tersebut dapat terjadi jika ada dispensasi yang diberikan pengadilan atau pejabat lain yang ditunjuk oleh kedua orang tua dari pihak pria maupun wanita (pasal 7 ayat 2). ${ }^{11}$

Berdasarkan data Jumlah penduduk Desa Pontang Tahun 2019, dapat dilihat bahwa dari jumlah 3.749 Kepala Keluarga (KK), masih terdapat 613 kepala keluarga (KK) atau $16,35 \%$ yang tergolong sebagai keluarga pra sejahtera atau keluarga miskin. Angka ini masih jauh lebih tinggi daripada angka kemiskinan secara nasional. Berdasarkan data Badan Pusat Statistik (BPS),

\footnotetext{
${ }^{11}$ Undang-undang Nomor 16 Tahun 2019 tentang
}

angka kemiskinan nasional tahun 2019 cenderung turun di angka $9,22 \% .^{12}$

Kemiskinan merupakan kondisi dimana seseorang atau sekelompok orang, laki-laki dan perempuan, tidak terpenuhi hak-hak dasarnya untuk mempertahankan dan mengembangkan kehidupan yang bermartabat. Definisi ini beranjak dari pendekatan berbasis hak yang mengakui bahwa masyarakat miskin mempunyai hak-hak dasar yang sama dengan anggota masyarakat lainnya. Kemiskinan tidak lagi dipahami hanya sebatas ketidakmampuan ekonomi, tetapi juga kegagalan memenuhi hakhak dasar dan perbedaan perlakuan bagi seseorang atau sekelompok orang dalam menjalani kehidupan secara bermartabat.

Kemiskinan merupakan keadaan ketika seseorang atau sekelompok orang tidak mampu mencukupi tingkat kemakmuran ekonomi yang dianggap sebagai kebutuhan minimal dari standar hidup tertentu. Disamping itu, kemiskinan juga memiliki keterkaitan dengan tingkat maupun kualitas pendidikan seseorang. Berdasarkan data penduduk Desa Pontang, keadaan masyarakat dengan mata pencaharian sebagai buruh tani dan buruh migran ini berdampak pada relatif rendahnya tingkat pendidikan warga desa Pontang. Sebagian besar pendidikan

Perubahan Atas Undang-Undang Nomor 1 Tahun 
1974 tentang Perkawinan

${ }^{12}$ https://mediaindonesia.com/read/detail/283554bps-angka-kemiskinan-indonesia-turun-jadi-922persen, diunduh 8 April 2020, jam 9.25 WIB. 
penduduk desa Pontang berpendidikan tingkat Sekolah Dasar (SD).

Penduduk miskin yang umumnya berpendidikan rendah, hal ini karena mereka harus bekerja kerasa apa saja untuk mempertahankan hidupnya dan keluarganya. Kondisi demikian menyebabkan lemahnya posisi tawar masyarakat miskin dan tingginya kerentanan terhadap perlakuan yang merugikan mereka. Disisi lain, masyarakat miskin juga harus menerima pekerjaan dengan imbalan yang terlalu rendah. Kesulitan ekonomi yang dihadapi keluarga miskin seringkali memaksa anak dan perempuan untuk bekerja.

Kemiskinan dan rendahnya tingkat pendidikan ini juga berdampak pada pengetahuan masyarakat terhadap peraturan prundang-undangan. Dalam hal ini pengetahuan tentang Undang-Undang Nomor 1 Tahun 1974 Tentang Perkawinan, secara khusus tentang batasan usia minimal untuk melangsungkan perkawinan. Berdasarkan hasil kuesioner yang diberikan kepada masyarakatDesa Pontang untuk usia diatas 50 tahun sebagian besar masyarakat melakukan perkawinan dibawah umur atau tidak sesuai dengan peraturan UndangUndang Nomor1 Tahun 1974 tentang perkawinan. Hal ini disebabkan karena pada waktu mereka melangsungkan perkawinan, peraturan tentang batasan usiauntuk melangsungkan perkawinan belum ada.
Didalam masyarakat tradisional hukum adat memang tidak mengenal batasan umur dewasa ataupun belum dewasa. Hukum Adat hanya mengenal secara insidental saja apakah seseorang itu, berhubungan dengan umur dan perkembangan jiwanya patut dianggap cakap atau tidak, mampu atau tidak mampu melakukan perbuatan hukum tertentu dalam hubungan hukum tertentu pula.Keadaan yang dianggap belum cakap artinya belum mampu memperhitungkan dan memelihara kepentingannya sendiri. Sedangkan cakap artinya telah mampu memperhitungkan dan memelihara kepentingan sendiri.

Apabila kedewasaan itu dihubungkan dengan perbuatan untuk melangsungkan perkawinan, maka hukum adat mengakui kenyataan bahwa apabila seorang pria dan wanita itu kawin dan mendapat anak, mereka dinyatakan dewasa. Ukuran mengenai kedewasaan menurut hukum adat lebih condong kepada sisi kepribadian seseorang seperti sudah baligh, mampu mencari nafkah, bertanggung jawab untuk diri sendiri dan mampu berkeluarga dan mendapatkan keturunan. Pengaturan mengenai perkawinan yang dilangsungkan dibawah umur dalam hukum adat memang tidak ada.

Hasil temuan peneliti di lapangan masyarakat Desa Pontang tentang peruba- 
han peraturan tentang batasan usia minimal

untuk melakukan perkawinan sebagaimana 
diatur dalam Undang-Undang Nomor 16 Tahun 2019 Tentang Perubahan UndangUndang Nomor 1 Tahun 1974tentang perkawinan, belum ada masyarakat yang mengetahuinya.

Sebagaimana diketahui bahwa hal penting yang diatur dalam Undang-Undang Nomor 16 Tahun 2019 Tentang Perubahan Undang-Undang Nomor 1 Tahun 1974 tentang perkawinan adalah adanya perubahan tentang batasan usia minimal untuk melangsungkan perkawinan. Undang-Undang Nomor 16 Tahun 2019 Tentang Perubahan Undang-Undang Nomor 1 Tahun 1974 tentang perkawinan menyatakan perubahan dimana batasan usia minimal untuk melakukan perkawinan pada Undang-Undang No 1 Tahun 1974 batasan minimal usia perkawinan bagi wanita ialah 16 Tahun dan untuk laki-laki 19 tahun dirubah menjadi 19 Tahun baik untuk wanita maupun laki-laki.

Berdasarkan hasil data kuesioner terhadap masyarakat miskin diperoleh data bahwa semua masyarakat tersebut tidak mengetahui tentang adanya perubahan batasan minimal untuk melangsungkan perkawinan juga tidak mengetahui tentang adanya peraturan Undang-Undang No.16 Tahun 2019 yang menyebutkan perubahan batasan usia minimal perkawinan. Hal ini disebabkan oleh belum adanya informasi dalam bentuk sosialisasi dari perangkat desa terkait dengan perubahan aturan diatas.
Berdasarkan hasil wawancara Peneliti dengan aparat Desa Pontang ${ }^{13}$ tentang Undang-Undang Nomor 16 Tahun 2019 Tentang Perubahan Undang-Undang Nomor 1 Tahun 1974Tentang Perkawinan, diperoleh informasi bahwahingga saat ini seluruh aparat Desa Pontang tidak mengetahui adanya undang-undang tersebut. Aparat Desa Pontang juga belum mengetahui tentang adanya perubahan batasan usia minimal untuk melakukan perkawinan pada Undang-Undang No 1 Tahun 1974 batasan minimal usia perkawinan bagi wanita ialah 16 Tahun dan untuk laki-laki 19 tahun dirubah menjadi 19 Tahun baik untuk wanita maupun laki-laki.

Ketidaktahuan masyarakat dan aparat desa tersebut disebabkan oleh keterbatasan informasi masyarakat desa dan belum adanya sosialisasi dari Pemerinatah Daerah Kabupaten Jember tentang adanya UndangUndang No 16 Tahun 2019 Tentang Perubahan Undang-Undang Nomor 1 Tahun 1974 tentang perkawinan. Belum adanya sosialisasi dari Pemerintah Daerah sehingga pemerintah desa juga belum melakukan sosialisasi kepada masyarakat.

Setiap manusia baik secara individu maupun kelompok telah memiliki perilaku yang berbeda. Ada yang sebagian orang berperilaku selalu mempertimbangkan

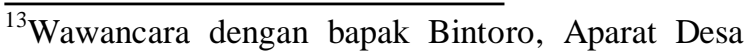


Pontang pada tanggal 1 April 2020 jam 09.00 WIB. 
segala aspek di sekitarnya dan sebagian lagi bertindak sesukanya. Pengetahuan merupakan domain yang sangat penting dalam terbentuknya suatu tindakan. Dengan demikian terbentuknya sikap seseorang disebabkan oleh adanya pengetahuan yang ada pada dirinya dan terbentuk suatu perilaku baru terutama yang ada pada orang dewasa dimulai pada domain kognitif.

Begitu pula kaitannya dengan pemahaman masyarakat tentang pembatasan usia minimum untuk melangsungkan perkawinan berdasarkan UU No. 16 Tahun 2019 Tentang Perubahan Atas UU 1 Tahun 1974 Tentang Perkawinan terhadap perkawinan dibawah umur di Desa Pontang Kecamatan Ambulu, Kabupaten Jember. Pemahaman masyarakat tentang batasan minimal usia untuk melangsungkan perkawinan akan berdampak pada adanya perilaku masyarakat untuk melangsungkan perkawinan terhadap anak yang masih dibawah umur.

Berdasarkan hasil kuesioner yang dibagikan kepada masyarakat miskin di Desa Pontang, diperoleh hasil bahwa masih terdapat perkawinan dibawah umur meskipun jumlahnya tidak banyak.Perkawinan dibawah umur dalam hal ini adalah perkawinan yang dilakukan dibawah batas minimal umur yang ditentukan dalam Undangundang Nomor 1 Tahun 1974 Tentang Perkawinan. Dalam arti bahwa perkawinan tersebut telah berlangsung sebelum lahirnya Undang-Undang Nomor 16 tahun 2019 
Tentang Perubahan Atas UU 1 Tahun 1974 Tentang Perkawinan. Sebagaimana diketahui bahwa dalam Undang-Undang Nomor 1 Tahun 1974 tentang Perkawinan, umur minimal untuk diizinkan melangsungkan perkawinan, yaitu pria 19 tahun dan wanita 16 tahun(Pasal 7 ayat 2).

Sedangkan ketentuan dalam Pasal 7 Ayat 1 Undang-Undang No. 1 Tahun 1974 tersebut telah diubah oleh Undang-Undang Republik Indonesia Nomor 16 Tahun 2019 tentang Perubahan Atas Undang-Undang Nomor 1 Tahun 1974 tentang Perkawinan disahkan pada tanggal 14 Oktober 2019. Pasal 7 ayat (1) Undang-Undang Nomor 1 Tahun 1974 menyatakan bahwa perkawinan hanya diizinkan apabila pihak pria mencapai umur 19 (sembilan belas) tahun dan pihak wanita sudah mencapai usia 16 (enam belas) tahun, dirubah bagi wanita dipersamakan dengan batas minimal umur perkawinan bagi pria, yaitu 19 (sembilan belas) tahun.

Ketentuan tentang batas umur pihak wanita sudah mencapai usia 16 (enam belas) tahun dalamPasal 7 Ayat 1 UndangUndang No. 1 Tahun 1974 tersebut memungkinkan terjadinya perkawinan dalam usia anak pada anak wanita. Hal ini karena dalam Pasal 1 angka 1 Undang-Undang tentang Perubahan Atas Undang-Undang Nomor 23 Tahun 2002 tentang Pelindungan Anak didefinisikan bahwa anak adalah seseorang yang belum berusia 18 (delapan 
belas) tahun, termasuk anak yang masih dalam kandungan.

Batas usia 19 (Sembilan belas) tahun bagi wanita dinilai telah matang jiwa raganya untuk dapat melangsungkan perkawinan agar dapat mewujudkan tujuan perkawinan secara baik tanpa berakhir pada perceraian dan mendapat keturunan yang sehat dan berkualitas. Dengan perubahan inidiharapkan laju kelahiran yang lebih rendah dan menurunkan resiko kematian ibu dan anak. Selain itu diharapkan juga dapat terpenuhinya hak-hak anak,antara lain tumbuh kembang anak lebih optimal, termasuk pendampingan orang tua serta memberikan akses anak terhadap pendidikan setinggi mungkin.

Berdasarkan hasil wawancara Peneliti dengan aparat Desa Pontangtentang tentang perkawinan dibawah umur yang terjadi di desa Pontang, diperoleh informasi bahwa hingga saat ini di desa Pontang masih terjadi perkawinan dibawah umur meskipun jumlahnya tidak terlalu banyak.Namun demikian, aparat desa tidak memiliki data yang lengkap tentang jumlah perkawinan dibawah umur. Hal ini disebabkan oleh karena pengurusan terkait dengan perkawinan dibawah umur terutama yang berhubungan dengan diterimanya datau ditolaknya permohonan untuk melangsungkan perkawinan adalah wewenang lembaga pencatat perkawinan, dalam hal ini adalah Kantor Urusan Agama (KUA). Apabila ada ke- 
pengurusan surat menyurat yang terkait

dengan perkawinan dibawah umur, maka aparat desa mengarahkan hal tersebut untuk diurus di Kantor Urusan Agama setempat. ${ }^{14}$ Sebagaimana diketahui bahwa dalam Undang-Undang Nomor 1 tahun 1974 tentang Perkawinan maupun Undang-Undang Nomor 16 Tahun 2019 tentang Perubahan Atas Undang-Undang Nomor 1 Tahun 1974 tentang Perkawinan,tidak ada larangan untuk melangsungkan perkawinan dibawah umur secara eksplisit. Dalam pasal 7 ayat

(2) Undang-Undang Nomor 16 Tahun 2019 tentang Perubahan Atas Undang-Undang Nomor 1 Tahun 1974 tentang Perkawinan disebutkan bahwadalam hal terjadi penyimpangan terhadap ketentuan umur tersebut, orang tua pihak pria dan/atau orang tua pihak wanita dapat meminta dispensasi kepada Pengadilan dengan alasan sangat mendesak disertai bukti-bukti pendukung yang cukup.

\footnotetext{
${ }^{14}$ Hasil Wawancara dengan bapak Bintoro, Aparat Desa Pontang pada tanggal 1 April 2020 jam 09.30 WIB.
} 


\section{KESIMPULAN}

Berdasarkan uraian diatas, dapat ditarik beberapa kesimpulan sebagai berikut:

1. Kemiskinan dan rendahnya tingkat pendidikan ini juga berdampak pada pengetahuan masyarakat terhadap peraturan prundang-undangan. Dalam hal ini pengetahuan tentang Undang-Undang Nomor 1 Tahun 1974 Tentang Perkawinan, secara khusus tentang batasan usia minimal untuk melangsungkan perkawinan. Berdasarkan hasil kuesioner yang diberikan kepada masyarakat Desa Pontang semua masyarakat tersebut tidak mengetahui tentang adanya perubahan batasan minimal untuk melangsungkan perkawinan juga tidak mengetahui tentang adanya peraturan Undang-Undang No.16 Tahun 2019 yang menyebutkan perubahan batasan usia minimal perkawinan. Hal ini disebabkan oleh belum adanya informasi dalam bentuk sosialisasi dari perangkat desa terkait dengan perubahan aturan diatas. Demikian pula dengan Aparat Desa Pontang juga belum mengetahui tentang adanya perubahan batasan usia minimal untuk melakukan perkawinan pada Undang-Undang No 1 Tahun 1974 batasan minimal usia perkawinan bagi wanita ialah 16 Tahun dan untuk laki- laki 19 tahun dirubah menjadi 19 Tahun baik untuk wanita maupun laki-laki. 
2. Berdasarkan hasil kuesioner yang dibagikan kepada masyarakat miskin di Desa Pontang, diperoleh hasil bahwa masih terdapat perkawinan dibawah umur meskipun jumlahnya tidak banyak. Namun demikian, aparat desa tidak memiliki data yang lengkap tentang jumlah perkawinan dibawah umur.Hal ini disebabkan oleh karena pengurusan terkait dengan perkawinan dibawah umur terutama yang berhubungan dengan diterimanya datau ditolaknya permohonan untuk melangsungkan perkawinan adalah wewenang lembaga pencatat perkawinan, dalam hal ini adalah Kantor Urusan Agama (KUA).

\section{DAFTAR PUSTAKA}

\section{Buku}

Abdul Kadir Muhammad, Hukum Perdata Indonesia, (Bandung: Citra Aditya Bakti, 2001

Amir Syarifuddin, Hukum Perkawinan Islam di Indonesia, antara Figh Munakahat dan Undang-Undang Perkawinan, (Jakarta: Kencana, 2006),

Hilman Hadikusuma, Hukum Perkawinan Indonesia Menurut Perundangan, Hukum Adat, Hukum Agama, (Bandung: Mandar Maju, 1990), 
Peter Mahmud Marzuki, Penelitian Hukum,

Prenada Media, Jakarta, 2006,

Philipus M Hadjon dan Tatik Sri Djatmiati,

Argumentasi Hukum, Gajah Mada

University Press, Yogyakarta, 2005,

Rahmat Hakim, Hukum Perkawinan Islam,

(Bandung: CV Pustaka Setia, 2000

Soerjono Soekanto, Sosiologi Keluarga

Tentang Ikhwal Keluarga, Remaja dan Anak, (Jakarta: Rineka Cipta, 2009),

Soerojo Wignjodioera, Pengantar dan Asasasas Hukum Adat,(Jakarta: Gunung Agung, 1995),

\section{Peraturan Perundang-undangan}

Kitab Undang-undang Hukum Perdata (KUH Perdata)

Undang-Undang Nomor 1 Tahun 1974

Tentang Perkawinan

Undang-Undang Republik Indonesia Nomor 16 Tahun 2019 tentang Perubahan Atas Undang-Undang Nomor 1 Tahun 1974 tentang Perkawinan

Kompilasi Hukum Islam (KHI)

Peraturan Pemerintah nomor 9 Tahun 1975 tentang Pelaksanaan UndangJURNAL RECHTENS, Vol. 9, No. 1, Juni 2020
Tentang Perkawinan

Dokumen RPJMDes Desa Pontang Tahun 2016-2021

\section{INTERNET}

https://mediaindonesia.com/read/detail/283

554-bps-angka-kemiskinan-indonesia-

turun-jadi-922-persen,

\section{HASIL WAWANCARA}

Wawancara dengan bapak Bintoro, Aparat Desa Pontang pada tanggal 1 April 2020.

\section{BIODATA SINGKAT PENULIS}

Supiantoadalah Dosen tetap pada Fakultas Hukum Universitas Islam Jember. Menyelesaikan pendidikan sarjana pada Fakultas Hukum Universitas Islam Jember dan Magister Hukum pada Program Magister Ilmu Hukum Fakultas Hukum Universitas Jember.

Nanang Tri Budiman adalah Dosen tetap pada Fakultas Hukum Universitas Islam Jember. Menyelesaikan pendidikan sarjana pada Fakultas Hukum Universitas Jember dan Magister Hukum pada Program Magister Ilmu Hukum Fakultas Hukum Universitas Narotama Surabaya.

Dwi Fefri Kurniasari adalah Tenaga Kependidikan Fakultas Hukum Universitas Islam Jember. Menyelesaikan pendidikan 
sarjana pada Fakultas Hukum Universitas

Islam Jember . 